\title{
Cooking and the Human Commitment to a High-quality Diet
}

\author{
R.N. CARMODY AND R.W. WRANGHAM \\ Department of Human Evolutionary Biology, Harvard University, Cambridge, Massachusetts 02138 \\ Correspondence: wrangham@fas.harvard.edu
}

\begin{abstract}
For our body size, humans exhibit higher energy use yet reduced structures for mastication and digestion of food compared to chimpanzees, our closest living relatives. This suite of features suggests that humans are adapted to a high-quality diet. Although increased consumption of meat during human evolution certainly contributed to dietary quality, meat-eating alone appears to be insufficient to support the evolution of these traits, because modern humans fare poorly on raw diets that include meat. Here, we suggest that cooking confers physical and chemical benefits to food that are consistent with observed human dietary adaptations. We review evidence showing that cooking facilitates mastication, increases digestibility, and otherwise improves the net energy value of plant and animal foods regularly consumed by humans. We also address the likelihood that cooking was adopted more than 250,000 years ago (kya), a period that we believe is sufficient in length for the proposed adaptations to have occurred. Additional experimental work is needed to help discriminate the relative contributions of cooking, meat eating, and other innovations such as nonthermal food processing in supporting the human transition toward dietary quality.
\end{abstract}

The allocation of energy to different tissues and the total use of energy are critical variables influencing a wide range of biological functions. Here, we review evidence suggesting that humans have adapted evolutionarily to having high-energy budgets as a result of unique aspects of the diet.

Using standard metabolic equations and detailed activity data, Leonard and Robertson (1997) determined mass-specific energy expenditure for 17 nonhuman primate species and two groups of human foragers (!Kung and Ache). Using their data, we calculate that, on average, male foragers expend $44 \%$ more energy than do male chimpanzees (Pan troglodytes) per unit body weight (i.e., TEE/BW ${ }^{0.792}$ : male forager $=118 \mathrm{kcal} / \mathrm{d} / \mathrm{kg}^{0.792}$; male chimpanzee $=82$ $\mathrm{kcal} / \mathrm{d} / \mathrm{kg}^{0.792}$, where TEE = total daily energy expenditure, and $\mathrm{BW}=$ body weight). This is partly due to male foragers traveling $10-20 \mathrm{~km} / \mathrm{d}$ and expending $\sim 40 \%$ of their total energy budget on activity, compared to $3-5 \mathrm{~km} / \mathrm{d}$ and $29 \%$ for chimpanzees (Leonard and Robertson 1997). Likewise, female foragers are estimated to expend $17 \%$ more energy than do female chimpanzees (TEE/BW ${ }^{0.792}$ : female forager $=91 \mathrm{kcal} / \mathrm{d} / \mathrm{kg}^{0.792}$; chimpanzee female $=78 \mathrm{kcal} / \mathrm{d} / \mathrm{kg}^{0.792}$ ). The figures for females do not include the lifetime costs of gestation and lactation, which should be higher in humans thanks to our shorter interbirth intervals (Coelho 1986; Aiello and Key 2002).

To achieve their high TEE, humans must consume more food and/or foods of higher energy density compared to chimpanzees. Because humans eat less and invest less in digestive structures than do chimpanzees, energy density is the principal solution (Wrangham 2009). Compared to nonhuman primates, humans have smaller oral cavities, reduced molar dentition, more gracile mandibles, and smaller chewing muscles relative to body size, all of which combine to confer less mastication ability (Wrangham 2009). These differences appear to be functional; whereas chimpanzees in the wild spend 4-6 h/d chewing their food, humans typically spend $<1 \mathrm{~h}$ (Wrangham and Conklin-Brittain 2003). In addition, humans have relatively shorter, less massive, and less sacculated intestinal tracts (Milton and Demment 1988; Aiello and Wheeler 1995), and comparing the relative sizes of intestinal segments, humans have virtually no caecum and substantially reduced colons, suggesting less reliance on microbial fermentation of fiber (Milton 1987). Our physiological investment in digestion also appears to be lower than expected: Humans expend an average of $6 \%-7 \%$ of meal energy in digestion, compared to the mammalian average of $13 \%-16 \%$ (Boback et al. 2007).

Traditionally, such dietary adaptations have been attributed in large part to increased consumption of animal foods (Shipman and Walker 1989; Milton 1999; Bunn 2006). Meat eating has clearly been important in human evolution. First, it is known that stone tools were used to process meat beginning at least 2.5 million years ago (mya) (Toth and Schick 2006). Second, bone strontium/ calcium $(\mathrm{Sr} / \mathrm{Ca})$ ratios, which tend to correlate inversely with trophic level, place early hominid diets between contemporary carnivores and herbivores, suggesting substantial consumption of animal foods (Sillen et al. 1995). Third, taeniid tapeworms are host-specific parasites for whom carnivores are definitive hosts and herbivores are intermediate hosts. Three species, Taenia saginata, T. asiatica, and T. solium, use humans exclusively as their primary host, indicating the occurrence of human meat consumption more than $\sim 1$ mya (Henneberg et al. 1998; Hoberg et al. 2001). Fourth, humans lack the ability to efficiently synthesize from plant-based raw materials the long-chain polyunsaturated fatty acids (PUFA) required for cell membrane growth, structure and function, and fetal and postnatal brain development (Clandinin 1999; 
Broadhurst et al. 2002). Preformed docosahexaenoic acid (DHA) and arachidonic acid (AA), which together comprise almost all PUFA in the central nervous system, are uniquely available from animal foods (Broadhurst et al. 2002). Fifth, similar to obligate carnivores (Hedberg et al. 2007), humans exhibit diminished ability to synthesize taurine from precursor amino acids (Hayes and Sturman 1981; Chesney et al. 1998). Taurine is found only in animal tissue and is thought to have been consumed sufficiently to reduce selective pressure for in vivo synthesis (Mann 2007). Finally, meat constitutes a large percentage of the diet for modern humans. Whereas chimpanzees typically obtain $<5 \%$ of their diet from animal foods, meat (hunted + fished) was found to provide $\geq 50 \%$ of dietary energy for $73 \%$ of 229 hunter-gatherer societies (Cordain et al. 2000).

Despite the importance of meat in human evolution, recent evidence also indicates that human diets, whether or not they include meat, are energetically inadequate if eaten raw. All human populations, regardless of environment or available materials, cook their food (Harris 1992; Wrangham and Conklin-Brittain 2003). The only groups that live for months or more on raw food are "raw foodists" living in industrial societies that forego cooked food for a variety of philosophical and perceived health reasons (Wrangham 2009). To date, all studies of raw foodists have concluded that a raw food diet provides insufficient energy for the maintenance of body weight (Carmody and Wrangham 2009). In the most extensive study - a cross-sectional survey of 572 long-term raw foodists living in Germany-Koebnick et al. (1999) found that body mass index (BMI) was inversely correlated with both the proportion of raw food in the diet and the length of time since adoption of raw foodism (Fig. 1). Odds of becoming underweight were three times greater for subjects following a $100 \%$ raw food diet compared to subjects following a $<80 \%$ raw food diet. Energy deficiency in subjects following a $100 \%$ raw food diet was

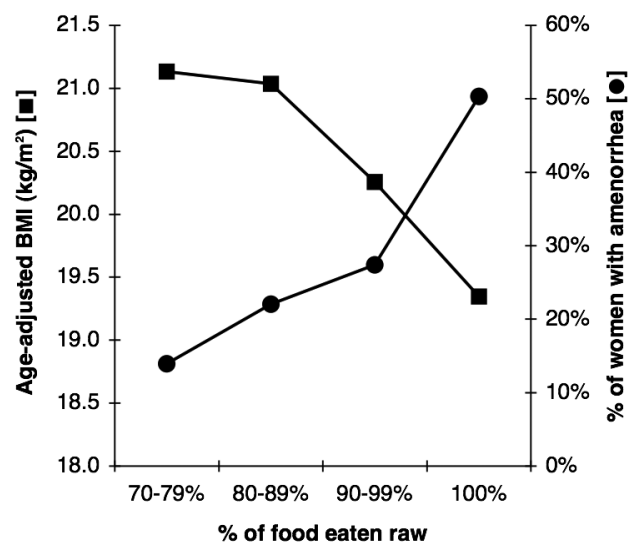

Figure 1. Energy deficiency among raw foodists. Age-adjusted BMI (left axis, closed box) and percentage of nonpregnant female subjects $<45$ years old reporting amenorrhea (right axis, closed circle) as a function of the percentage of food eaten raw. (Adapted from Koebnick et al. 1999.) apparently responsible for $50 \%$ of female subjects of child-bearing age reporting amenorrhea, and an additional 10\% reported suffering from menstrual irregularities. The incidence of menstrual disruption scaled with the proportion of raw food in the diet and the duration of raw foodism, conforming to the expected dependence of female reproductive capacity on energy status (Ellison et al. 1993; Ellison 2003). Critically, Koebnick et al. (1999) found no difference in the odds of being underweight or amenorrhea occurring among meat-eating, vegetarian, or vegan subjects, suggesting that the consumption of meat alone did not improve energy status.

Unlike a raw diet, lack of meat does not hinder energy status or reproductive function. In the United States, median BMIs of vegetarians eating cooked diets were 23.7 (women) and 24.3 (men), close to the median BMIs of those eating typical American mixed diets (24.8 [women] and 25.3 [men]) (Carmody and Wrangham 2009). In contrast, median BMIs for vegetarians eating predominantly raw diets were 20.1 (women) and 20.7 (men). In addition, women consuming cooked vegetarian diets exhibit no suppression of ovarian function compared to women consuming cooked diets that include meat (Barr 1999), nor are there differences in the age of menarche between vegetarian and omnivorous women eating cooked diets (Rosell et al. 2005).

Evidence of poor energy status among contemporary raw foodists is surprising. First, raw foodists tend to live in urban areas with abundant, year-round access to a wide variety of high-quality foods, including meats, bone marrow, domesticated plants, and oils (Hobbs 2005; Wrangham 2009). Second, most raw foodists process their foods heavily, using methods such as sprouting, freezing, blending, juicing, mechanically tenderizing, pickling, coldpressing, cold-smoking, and even drying at up to $\sim 45^{\circ} \mathrm{C}$ (Koebnick et al. 1999; Hobbs 2005; Wrangham 2009). These methods alter the foods in ways likely to increase energy value (see below). Third, chimpanzees would unquestionably fare well on a human raw food diet, with its superabundant and stable access to foods with lower fiber concentrations than those available in the wild (Wrangham and Conklin-Brittain 2003).

Such data suggest that in the wild, humans eating raw diets would not normally obtain sufficient energy to thrive and therefore the diet to which humans are evolutionarily adapted is obliged to include cooked food (Wrangham and Conklin-Brittain 2003). According to this hypothesis, cooking of plant and animal foods provides energetic benefits beyond those conferred by meat eating alone. This stable source of supplemental energy would have supported the adaptations for high dietary quality that we observe today, including reduced structures for mastication and digestion, coupled with a large total energy budget.

This hypothesis makes three predictions that we examine in this paper. First, for cooking to have allowed for reduced chewing ability, it must make foods easier to masticate. Second, for cooking to have supported the reduction in gut size, it must make foods more digestible. Third, cooking must lead to higher net energy gains. 


\section{EFFECTS OF COOKING ON EASE OF CHEWING}

Cooking reduces the structural integrity of most foods, leading to a reduction of chewing time and masticatory strain (Lieberman et al. 2004; Lucas 2004). With respect to plant materials, heat degrades the pectic polysaccharides that cause plant cell walls to adhere and hence causes a collapse of tissue structure and a loss of firmness (Jarvis et al. 2003; Waldron et al. 2003). This process applies to many plant foods regularly consumed by humans, including roots (see, e.g., Dominy et al. 2008), fruits (see, e.g., Qi et al. 2000), and stems (see, e.g., Lin and Chang 2005). As a result of this process, cooked plant foods are more easily masticated, requiring fewer chewing cycles and a shorter time in the mouth before they form a coherent bolus and are swallowed (Engelen et al. 2005). For example, Dominy et al. (2008) found that the wild tubers regularly eaten by Hadza foragers were generally too fracture resistant for human consumption until they were cooked. Light roasting over a traditional fire reduced the work of fracture by $40 \%$ $59 \%$, depending on the species and tissue sampled, improving edibility and reducing the cost of mastication (Dominy et al. 2008).

Cooking has also been shown to tenderize several animal foods (e.g., pig, beef, goat, rabbit, and octopus; Wrangham 2009). However, the effects of heat on the mechanical properties of muscle tissue are complex. Muscle tissue consists of protein-rich muscle fibers embedded in a lattice of fat and a tough collagen-rich connective tissue that derives its strength from a triplehelix arrangement of protein strands. When heated above $40^{\circ} \mathrm{C}$, muscle proteins begin to denature and coil, producing contraction of the muscle along the grain. This contraction increases with longer cooking time and higher cooking temperature, leading to progressive toughening of the muscle fibers. At the same time, the collagen surrounding each muscle fiber remains difficult to chew until heated to $60^{\circ} \mathrm{C}-70^{\circ} \mathrm{C}$, when collagen begins to be hydrolyzed into gelatin. As gelatinization of collagen proceeds, muscle fibers separate and meat becomes more easily fractionated along the grain (Barham 2001; McGee 2004). Therefore, the effects of cooking on meat tenderness reflect a trade-off between tender muscle fibers and tough collagen at low temperatures and tough muscle fibers and tender collagen at high temperatures. The amount of collagen present in the meat is consequently an important factor, with collagen-rich meats (i.e., active or weight-bearing muscles, older animals) requiring longer cooking and higher temperatures to achieve maximum tenderness, whereas meats with lower collagen (i.e., infrequently used muscles, more fat marbling, younger animals) are best cooked quickly (Purslow 2005; Lepetit 2008). Wild meats available to ancestral humans would undoubtedly have been collagen rich and therefore would have required long cooking and/or high heat to achieve tenderization. Roasting meat over an open fire, a technique commonly used by traditional foragers, would likely achieve such a result.

\section{EFFECTS OF COOKING ON DIGESTIBILITY}

Starchy plant foods are important staples in almost all human societies (Atkins and Bowler 2001). Raw starch granules are semicrystalline mixtures of amylopectin and amylose plus trace amounts of protein and lipid. They are normally resistant to hydrolysis by salivary and pancreatic amylases. The degree of resistance to digestion of raw starch granules varies, with raw cereals tending to be less resistant to digestion than raw tubers, legumes, or green bananas (Carmody and Wrangham 2009). Heating acts to gelatinize starches, transforming their resistant semicrystalline structures into amorphous compounds that are more readily hydrolyzed to sugars and dextrins (Tester et al. 2006). Cooking thus functions to predigest starches, improving their nutritional availability to the human consumer, with the extent of predigestion being dependent on the temperature of processing and the amount of water present (Tester and Sommerville 2000).

To quantify the impact of cooking on starch digestibility, it is important to account for the fact that a significant and variable proportion of starch consumed by a human is digested not by the human but instead by gut microbes (Livesey 2002). Starches that escape digestion in the small intestine, called resistant starches, are fermented by microbes in the caecum and colon, generating short-chain fatty acids. This process returns only $\sim 50 \%$ of the metabolizable energy of the starch to the human consumer, owing to a combination of the less-efficient capture of energy as ATP during mammalian oxidation of short-chain fatty acids compared to glucose, the consumption of shortchain fatty acids for fuel by gut microbes, and losses during conversion due to the production of hydrogen and methane (Livesey 1995; Silvester et al. 1995; Carmody and Wrangham 2009). These diminished returns imply that traditional measures of digestibility based on nutrients passing through into the feces (i.e., fecal digestibility) are biologically irrelevant. The biologically relevant measure of starch digestibility can instead be estimated by summing the proportion of starch digested as of the terminal ileum (i.e., ileal digestibility) together with $50 \%$ of resistant starches. Applying this index to published reports of the human ileal digestibility of plant starches, cooking increased the digestibility of all varieties, with increases ranging from $12 \%$ for oats to $35 \%$ for green bananas (Carmody and Wrangham 2009). This suggests that cooking has a profound impact on the digestibility of human plant food staples and hence on the total net energy gain from eating these foods.

The disparity between ileal and fecal measures is even more pronounced for proteinaceous foods than for starchy foods because the products of microbial fermentation of protein appear to return zero energy to the consumer (Mason 1984; McNeil 1988). Unfortunately, there has been little investigation of the effects of cooking on the ileal digestibility of protein by humans, in part because of the complexities of distinguishing food proteins from endogenous (i.e., human) protein excretions present in the ileal effluent. The only study to resolve this problem examined the effect of cooking on the ileal digestibility of isotopically 
labeled egg protein (Evenepoel et al. 1998, 1999). In this study, ileostomates - people who, for health reasons, have undergone surgery to connect the terminal ileum to the surface of the skin, thus allowing ileal effluent to collect in an external pouch - consumed a homogeneous mixture of egg white and yolk, served either raw or microwaved. Evenepoel et al. (1998) determined that the ileal digestibility of egg protein was $51 \%$ for raw eggs and $91 \%$ for cooked eggs, meaning that cooking increased digestibility in these patients by $78 \%$. In addition, Evenepoel et al. $(1998,1999)$ controlled for the possibility that ileostomates exhibit atypical digestion by first demonstrating that recovery of isotopes in breath was positively correlated with ileal digestibility (Evenepoel et al. 1998) and then establishing that the breath recovery profiles of ileostomy patients and intact subjects were comparable (Evenepoel et al. 1999). This research revealed that, contrary to widespread belief in the high biological availability of raw egg protein, much of the raw egg protein benefited the intestinal microbes and not the human consumer.

Heat-induced denaturation of protein, the mechanism attributed by Evenepoel et al. $(1998,1999)$ to explain the increased digestibility of cooked eggs, is common to all forms of animal protein. When heated, proteins unwind from their tightly bound forms, losing their tertiary structures (i.e., covalent bonds, dipole-dipole interactions, and van der Waals interactions between amino acid side chains) and secondary structures (i.e., repeating patterns such as $\alpha$ helices and $\beta$-pleated sheets). Denatured proteins adopt a random coil configuration that makes proteins more digestible by increasing their susceptibility to proteolytic enzymes (Davies et al. 1987). It has therefore been suggested that cooking may make all animal proteins more digestible (Lawrie 1991; Gaman and Sherrington 1996).

Heat also has contrary effects on proteins. When heated in the presence of reducing sugars, proteins participate in the Maillard reaction, a nonenzymatic condensation of amino acids and sugars that is catalyzed by heat (Maillard 1916). The Maillard reaction produces a complex variety of melanoidins and aromatic compounds responsible for food browning and the development of characteristic smells and flavors. This process lowers protein digestibility (Seiquer et al. 2006). Mechanisms include the destruction of essential amino acids (Rerat et al. 2002), structural changes in protein that prevent normal enzymatic cleavage (Oste and Sjodin 1984; Kato et al. 1986), the impedance of epithelial transport (Shorrock and Ford 1978), and the inhibition of digestive enzymes (Oste et al. 1987). Maillard reactions are largely restricted to surfaces of meat. Their effects on ileal digestibility have not been studied, and their net contribution to reducing protein digestibility remains uncertain.

\section{EFFECTS OF COOKING ON NET ENERGY GAIN}

The net energy value of a food is a function of several factors, including its gross caloric value, digestibility, diet-induced thermogenesis, and impact on basal metabolic rate. We have already presented evidence that cook- ing improves the digestibility of starchy plant foods and may also contribute to protein digestibility. We discuss here evidence showing that cooking also lowers the costs of food consumption, including diet-induced thermogenesis and the metabolic costs of immune defense.

\section{Lowering Diet-induced Thermogenesis}

Diet-induced thermogenesis (DIT) refers to increased metabolic expenditure as a result of ingesting and assimilating a meal. DIT is also known as specific dynamic action, postprandial thermogenesis, or the thermic effect of feeding. In humans on a Western balanced diet, DIT accounts for $\sim 10 \%$ of the total energy budget, a proportion similar to that of locomotion (Westerterp 2004). Cooking appears to reduce DIT partly by softening and reducing the structural integrity of food, thus facilitating the mechanical work of the stomach and increasing access to foods by gastric acids and proteolytic enzymes (Secor 2003). These act to accelerate the gastric emptying rate, which corresponds closely to the overall rate and cost of digestion (Horowitz et al. 2002; Pera et al. 2002; Secor 2003).

Studies in vivo find that softer foods generate reduced DIT responses. Among rats, Oka et al. (2003) found that softening food pellets by the addition of air pockets led to reduced postprandial rises in body temperature, ultimately leading to greater weight gain and adiposity in soft-fed versus hard-fed animals despite similar levels of intake and activity. Among various species of reptiles and amphibians, meals of soft-bodied prey items led to lower DIT than equivalent meals of hard-bodied prey items (Secor and Faulkner 2002; Secor 2003; Secor and Boehm 2006).

Only one study has directly compared the effects of cooking and mechanical softening on DIT. Boback et al. (2007) fed Burmese pythons (Python molurus) meals of beef weighing $25 \%$ of the snake's body mass, served in one of four forms: raw and whole, raw and ground, cooked and whole, and cooked and ground. We found that cooking reduced DIT by $13 \%$ of meal energy, grinding reduced DIT by $12 \%$, and the effects of cooking and grinding were nearly additive, with the cooked and ground meal associated with a $23 \%$ reduction in DIT compared to the raw and whole treatment. That the combined (cooked and ground) treatment produced the lowest DIT revealed that the suppressive effects conferred by cooking were above and beyond those conferred by mechanical grinding. The difference is attributable to the gelatinization of collagen-rich connective tissues, a process that can be accomplished only via heat, as discussed above. How closely the results for pythons apply to human DIT is unknown. Metabolic demands differ extensively between poikilothermic and homeothermic animals, and pythons, unlike humans, exhibit substantial gastrointestinal remodeling between meals (Secor and Diamond 1995). For these reasons, it would be useful to directly measure the effects of cooking and grinding on DIT in humans. Although experimentally more challenging due to the confounding variables of activity expenditure and body temperature regulation, human metabolic chambers have been used successfully to estimate 24-hour DIT (Westerterp et al. 1999). 


\section{Lowering Metabolic Costs of Immune Defense}

Basal metabolic rate (BMR) is defined as the energy expended in a conscious, fasted body at rest in a thermally neutral environment (Kleiber 1961). BMR reflects the minimum energy sufficient to sustain vital processes, including cell function and replacement, synthesis and secretion of enzymes and hormones, maintenance of body temperature, uninterrupted work of cardiac and respiratory muscles, brain function, and immune defense (Durnin 1981). BMR accounts for $45 \%-70 \%$ of the total energy budget in humans, representing the largest component of energy expenditure (Black et al. 1996; FAO/WHO/UNU 2004). Cooking is proposed to reduce BMR by lowering investment in immune defense. For example, cooking kills meat-borne pathogens such as Escherichia coli, Salmonella, Campylobacter, Staphylococcus, and Listeria, which, if ingested live, typically result in multiple symptoms, including fever. Fever alone has been shown to increase resting metabolic rate (RMR) (which is conceptually equivalent to BMR but is more practical to measure because it does not require the subject to sleep overnight in situ before metabolic measurement) by $\sim 7 \%-15 \%$ for each $1{ }^{\circ} \mathrm{C}$ above standard temperature (DuBois 1937; Roe and Kinney 1965; Elia 1992). Using the often cited 13\% relationship measured by DuBois (1937), we estimated the annual cost of fever due to consumption of cooked agricultural meat products (beef, pork, mutton, and poultry) versus the implied annual cost of fever if those same meat products were consumed raw (Carmody and Wrangham 2009). We found that, with habitual cooking of these meat products, the estimated cost of immune up-regulation due to fever was $<0.01 \%$ of annual RMR. In contrast, if these products were consumed at similar rates without cooking, the estimated cost was $8.4 \%$ of annual RMR. Raw wild meat is expected to be less pathogen-bearing on average than raw meat raised and processed for mass-market consumption, so the impact of cooking may be somewhat overestimated. Nevertheless, our results suggest that meat consumption at contemporary Western levels would be energetically inefficient without cooking. Similar suppressive effects on immune regulation are likewise expected due to the role of heat in killing plant-borne pathogens, such as Giardia lamblia, as well as in degrading plant-borne antinutrients, such as tannins and phytates.

The role of cooking in reducing the costs of food consumption supports the hypothesis that cooking increases the net energy value of foods. Further in vivo studies focusing on the impact of cooked versus raw diets on wholeorganism factors such as growth and energy balance are needed to address the possibility that the factors contributing to net energy are not independent and thus distort the assessment of net energy effects. For example, it is reasonable to expect that digestibility (positive contributor to net energy) and DIT (negative contributor) are related, because higher levels of absorbable nutrients should theoretically increase the costs of absorption and postabsorptive processes such as membrane transport, ketogenesis, amino acid deamination and oxidation, glycogenesis, urea production, and renal excretion.

\section{OPPORTUNITY FOR EVOLUTIONARY ADAPTATION TO COOKED FOOD}

The hypothesis that humans are evolutionarily adapted to a diet of cooked food depends on sufficient time having elapsed since the control of fire and subsequent adoption of cooking for such evolution to have occurred.

No consensus exists as to when fire was first controlled, in part because traces of fire usually disappear quickly and thus leave no evidence for archaeologists to find (Sergant et al. 2006). Nevertheless, fire was certainly controlled by 250 kya. Several sites dated to 250 kya or older contain evidence of fire use by hominids, including burned deposits, fire-cracked rocks, reddened areas, baked clay, ash, charcoal, fire-hardened wood, burned lithics, burned bone, and even some indication of hearths (James 1989). Older dates for the control of fire are also widely acknowledged at sites such as Beeches Pit (Preece et al. 2006), Schöningen (Thieme 2005), and MénezDrégan (Monnier et al. 1994), all dated to 400 kya.

Given that wild chimpanzees have been observed to pick cooked seeds from the ashes of bush fires (Brewer 1978), it is hard to imagine that humans would have controlled fire for more than a few generations without discovering the benefits of cooking. Wobber et al. (2008) showed that captive great apes, when presented with a choice of five different foods served raw and cooked, significantly preferred the cooked item (meat, carrots, sweet potato) or were indifferent to the options (white potato, apple). In no case was the raw food preferred. At minimum, these results suggest that preference for cooked foods is not a recent evolutionary phenomenon (Wobber et al. 2008). It therefore seems reasonable to assume that hominids began cooking no later than 250 kya (Brace 1995; Ragir 2000). Given that human populations with a history of dairying developed the capacity for lactose digestion into adulthood at least twice within the last 7000 years (Bersaglieri et al. 2004; Tishkoff et al. 2007), there has clearly been ample time for adaptation to the expected effects of cooking.

Gene expression studies on cooked versus raw diets may ultimately enable discrimination of a molecular signal of adaptation to cooking. The relationship between genomic and phenotypic features is especially difficult to study in humans and our close genetic relatives because most experimental approaches are inappropriate. However, recent work by Somel et al. (2008) has demonstrated that mice can be used to study certain aspects of human-chimpanzee dietary divergence. Somel et al. (2008) reared groups of mice for 2 weeks on one of four experimental diets: mouse chow, chimpanzee food (raw, vegetarian), human cafeteria food (cooked, mixed), and human fast food (cooked, mixed). This short period of dietary divergence led to substantial differences in liver gene expression between groups of mice. Importantly, the specific genes involved and the directional differences observed between the mice fed chimpanzee food and the mice fed either type of human food mirrored $10 \%$ of the differences in liver gene expression observed between chimpanzees and humans. Thus, Somel et al. (2008) quickly replicated in mice a sizable 
fraction of the expression differences observed between humans and our closest living relatives. The relevant genes were found to have evolved more quickly in their promoter and amino acid sequences than by random chance, implying that changes in diet led directly to some genetic divergence between humans and chimpanzees. Because no differences were observed between the groups of mice eating the two human diets, despite large differences in caloric density and macronutrient composition, Somel et al. (2008) reasoned that the expression differences were caused by features that unite the two human diets while simultaneously distinguishing them from both the mouse diet and the chimpanzee diet. Although Somel et al. (2008) do not elaborate, they speculate that meat eating and/or cooking may have been responsible.

\section{CONCLUSIONS}

Strategies used by humans and our closest relatives to meet daily energy requirements have been the focus of much research during the last century. However, the significance of cooking - a unique and universal human behavior-has only recently begun to be considered (Aiello and Wheeler 1995; Wrangham et al. 1999; Wrangham and Conklin-Brittain 2003; Carmody and Wrangham 2009). Few experimental studies exist that enable us to directly evaluate the effects of cooking on human mastication (see, e.g., Dominy et al. 2008), digestibility (see, e.g., Evenepoel et al. 1998), or energy gain (see, e.g., Koebnick et al. 1999). Other predictions can currently only be evaluated by reference to animal models (see, e.g., Boback et al. 2007) or with indirect logic, such as the effect of cooking on food texture and its resulting implications for DIT (see, e.g., Oka et al. 2003).

The available evidence suggests that cooking induces physical and chemical changes in food that are consistent with human adaptations toward dietary quality. Our review shows that cooking facilitates mastication of plant and animal foods, compatible with our reduced molar dentition, more gracile mandibles, and smaller chewing muscles compared to chimpanzees. Cooking also increases the digestibility of starchy plant foods and animal proteins, compatible with our shorter less-massive and less-sacculated intestinal tracts. Cooking might also improve the net energy value of human foods through other pathways, including lowering the metabolic costs of digestion and immune defense.

Meat eating is clearly also important as a source of energy. Given that textural changes are at least partially responsible for the proposed positive effects of cooking, nonthermal processing methods that manipulate food texture, such as pounding or grinding, may likewise have contributed to raising net energy gains from the diet during human evolution. Yet, current data hint that neither meat eating nor nonthermal processing is sufficient to explain all of our digestive and energetic adaptations, given that modern raw foodists who consume meat products as well as heavily process their foods using sophisticated nonthermal techniques exhibit low energy status (Koebnick et al.
1999). Further studies are required that focus on the relative impacts of cooking, meat eating, and nonthermal processing on the material properties, digestibility, and net energy value of human foods. In addition, comparative studies of diet-induced gene expression may ultimately provide a molecular signal of dietary divergence between humans and our closest relatives. Such research will discriminate more finely the pathways by which humans transitioned toward obligate dietary quality.

\section{ACKNOWLEDGMENTS}

We thank the organizers for the invitation to participate in this Symposium volume. We are grateful to Stephen Secor, Adrian Briggs, Corinna Koebnick, Nancy Lou Conklin-Brittain, Charles Nunn, and Katherine Zink for valuable comments and discussion.

\section{REFERENCES}

Aiello LC, Key C. 2002. Energetic consequences of being a Homo erectus female. Am J Hum Biol 14: 551-565.

Aiello L, Wheeler P. 1995. The expensive-tissue hypothesis: The brain and the digestive system in human and primate evolution. Curr Anthropol 36: 199-221.

Atkins P, Bowler I. 2001. Food in society: Economy, culture, geography. Arnold, London.

Barham P. 2001. The science of cooking. Springer, Berlin.

Barr SI. 1999. Vegetarianism and menstrual cycle disturbances: Is there an association? Am J Clin Nutr 70: 549S-554S.

Bersaglieri T, Sabeti PC, Patterson N, Vanderploeg T, Schaffner SF, Drake JA, Rhodes M, Reich DE, Hirschhorn JN. 2004. Genetic signatures of strong recent positive selection at the lactase gene. Am J Hum Genet 74: 1111-1120.

Black AE, Coward WA, Cole TJ, Prentice AM. 1996. Human energy expenditure in affluent societies: An analysis of 574 doubly-labelled water measurements. Eur J Clin Nutr 50: 7292.

Boback SM, Cox CL, Ott BD, Carmody R, Wrangham RW, Secor SM. 2007. Cooking and grinding reduces the cost of meat digestion. Comp Biochem Physiol A 148: 651-656.

Brace C.L. 1995. The stages of human evolution. Prentice-Hall, Englewood Cliffs, NJ.

Brewer S. 1978. The forest dwellers. Collins, London.

Broadhurst CL, Wang YQ, Crawford MA, Cunnane SC, Parkington JE, Schmidt WF. 2002. Brain-specific lipids from marine, lacustrine, or terrestrial food resources: Potential impact on early African Homo sapiens. Comp Biochem Physiol $B$ 131: 653-673.

Bunn HT. 2006. Meat made us human. In Evolution of the human diet: The known, the unknown, and the unknowable (ed. PS Ungar), pp. 191-211. Oxford University Press, Oxford.

Carmody RN, Wrangham RW. 2009. The energetic significance of cooking. J Hum Evol (in press).

Chesney RW, Helms RA, Christensen M, Budreau AM, Han XB, Sturman JA. 1998. The role of taurine in infant nutrition. $A d v$ Exp Med Biol 442: 463-476.

Clandinin MT. 1999. Brain development and assessing the supply of polyunsaturated fatty acids. Lipids 34: 131-137.

Coelho AM. 1986. Time and energy budgets. In Comparative primate biology, Vol 2 (Part A): Behavior, conservation, and ecology (ed. G Mitchell and J Erwin), pp. 141-166. A.R. Liss, New York.

Cordain L, Miller JB, Eaton SB, Mann N, Holt SHA, Speth JD. 2000. Plant-animal subsistence ratios and macronutrient energy estimations in worldwide hunter-gatherer diets. $\mathrm{Am} \mathrm{J}$ Clin Nutr 71: 682-692.

Davies KJA, Lin SW, Pacifici RE. 1987. Protein damage and 
degradation by oxygen radicals. IV. Degradation of denatured protein. J Biol Chem 262: 9914-9920.

Dominy NJ, Vogel ER, Yeakel JD, Constantino P, Lucas PW. 2008. Mechanical properties of plant underground storage organs and implications for dietary models of early hominins. Evol Biol 35: 159-175.

DuBois EF. 1937. The mechanisms of heat loss and temperature regulation. Stanford University Press, Palo Alto, CA.

Durnin JVGA. 1981. Basal metabolic rate in man (Joint FAO/ WHO/UNU Expert Consultation on Energy and Protein Requirements, Rome). http://www.fao.org/docrep/meeting/004/ $\mathrm{M} 2845 \mathrm{E} / \mathrm{m} 2845 \mathrm{e} 00 . \mathrm{htm}$

Elia M. 1992. Energy expenditure to metabolic rate. In Energy metabolism: Tissue determinants and cellular corollaries (ed. JM McKinney and HN Tucker), pp. 19-49. Raven, New York.

Ellison PT. 2003. Energetics and reproductive effort. Am J Hum Biol 15: 342-351.

Ellison PT, Panter-Brick C, Lipson SF, O'Rourke MT. 1993. The ecological context of human ovarian function. Hum Reprod 8: 2248-2258.

Engelen L, Fontijn-Tekamp A, van der Bilt A. 2005. The influence of product and oral characteristics on swallowing. Arch Oral Biol 50: 739-746.

Evenepoel P, Geypens B, Luypaerts A, Hiele M, Rutgeerts P. 1998. Digestibility of cooked and raw egg protein in humans as assessed by stable isotope techniques. J Nutr 128: 1716-1722.

Evenepoel P, Claus D, Geypens B, Hiele M, Geboes K, Rutgeerts P, Ghoos Y. 1999. Amount and fate of egg protein escaping assimilation in the small intestine of humans. Am J Physiol 277: G935-G943

FAO/WHO/UNU. 2004. Human energy requirements (Joint FAO/ WHO/UNU Expert Consultation, Rome. Food and Nutrition Technical Report Series No. 1). http://www.fao.org/docrep/ 007/Y5686E/y5686e00.htm.

Gaman PM, Sherrington KB. 1996. The science of food: An introduction to food science, nutrition and microbiology. Pergamon, Oxford.

Harris D. 1992. Human diet and subsistence. In The Cambridge encyclopedia of human evolution (ed. S Jones et al.), pp. 6974. Cambridge University Press, Cambridge.

Hayes KC, Sturman JA. 1981. Taurine in metabolism. Annu Rev Nutr 1: 401-425.

Hedberg GE, Dierenfeld ES, Rogers QR. 2007. Taurine and zoo felids: Considerations of dietary and biological tissue concentrations. Zoo Biol 26: 517-531.

Henneberg M, Sarafis V, Mathers K. 1998. Human adaptations to meat eating. Hum Evol 13: 229-234.

Hobbs SH. 2005. Attitudes, practices, and beliefs of individuals consuming a raw foods diet. Explore 1: 272-277.

Hoberg EP, Alkire NL, de Queiroz A, Jones A. 2001. Out of Africa: Origins of the Taenia tapeworms in humans. Proc $R$ Soc Lond B 268: 781-787.

Horowitz M, O'Donovan D, Jones KL, Feinle C, Rayner CK, Samsom M. 2002. Gastric emptying in diabetes: Clinical significance and treatment. Diabet Med 19: 177-194.

James SR. 1989. Hominid use of fire in the Lower and Middle Pleistocene: A review of the evidence. Curr Anthropol 30: 1-26.

Jarvis MC, Briggs SPH, Knox JP. 2003. Intercellular adhesion and cell separation in plants. Plant Cell Environ 26: 977-989.

Kato Y, Matsuda T, Kato N, Watanabe K, Nakamura R. 1986. Browning and insolubilization of ovalbumin by the Maillard reaction with some aldohexoses. J Agric Food Chem 34: 351355.

Kleiber M. 1961. The fire of life: An introduction to animal energetics. Wiley, New York.

Koebnick C, Strassner C, Hoffmann I, Leitzmann C. 1999. Consequences of a long-term raw food diet on body weight and menstruation: Results of a questionnaire survey. Ann Nutr Metab 43: 69-79.

Lawrie RA. 1991. Meat science. Pergamon, Oxford.

Leonard WR, Robertson ML. 1997. Comparative primate energetics and hominid evolution. Am J Phys Anthropol 102: 265281.
Lepetit J. 2008. Collagen contribution to meat toughness: Theoretical aspects. Meat Sci 80: 960-967.

Lieberman DE, Krovitz GE, Yates FW, Devlin M, St. Claire M. 2004. Effects of food processing on masticatory strain and craniofacial growth in a retrognathic face. J Hum Evol 46: 655-677.

Lin CH, Chang CY. 2005. Textural change and antioxidant properties of broccoli under different cooking treatments. Food Chem 90: 9-15.

Livesey G. 1995. The impact of complex carbohydrates on energy balance. Eur J Clin Nutr 49: S89-S96.

Livesey G. 2002. Thermogenesis associated with fermentable carbohydrate in humans, validity of indirect calorimetry, and implications of dietary thermogenesis for energy requirements, food energy and body weight. Int J Obesity 26: 1553 1569.

Lucas P. 2004. Dental functional morphology: How teeth work. Cambridge University Press, Cambridge.

Maillard LC. 1916. A synthesis of humic matter by effect of amine acids on sugar reducing agents. Ann Chim France 5: 258-316.

Mann N. 2007. Meat in the human diet: An anthropological perspective. Nutr Diet 64: S102-S107.

Mason VC. 1984. Metabolism of nitrogenous compounds in the large gut. Proc Nutr Soc 43: 45-53.

McGee H. 2004. On food and cooking: The science and lore of the kitchen. Scribner, New York.

McNeil NI. 1988. Nutritional implications of human and mammalian large intestinal function. World Rev Nutr Diet 56: 1-42.

Milton K. 1987. Primate diets and gut morphology: Implications for hominid evolution. In Food and evolution: Towards a theory of human food habits (ed. M Harris and EB Ross), pp. 93115. Temple University Press, Philadelphia.

Milton K. 1999. A hypothesis to explain the role of meat-eating in human evolution. Evol Anthropol 8: 11-21.

Milton K, Demment MW. 1988. Chimpanzees fed high and low fiber diets and comparison with human data. J Nutr 118: 1082 1088.

Monnier JL, Hallegouet B, Hinguant S, Laurent M, Auguste P, Bahain JJ, Falgueres C, Gebhardt A, Marguerie D, Molines N, et al. 1994. A new regional group of the Lower Paleolithic in Brittany (France), recently dated by electron spin resonance. C R Acad Sci Ser II 319: 155-160.

Oka K, Sakuarae A, Fujise T, Yoshimatsu H, Sakata T, Nakata M. 2003. Food texture differences affect energy metabolism in rats. J Dent Res 82: 491-494.

Oste R, Sjodin P. 1984. Effect of Maillard reaction products on protein digestion: In vivo studies on rats. J Nutr 114: 2228-2234.

Oste RE, Miller R, Sjostrom H, Noren O. 1987. Effect of Maillard reaction products on protein digestion: Studies on pure compounds. J Agric Food Chem 35: 938-942.

Pera P, Bucca C, Borro P, Bernocco C, De Lillo A, Carossa S. 2002. Influence of mastication on gastric emptying. J Dent Res 81: 179-181.

Preece RC, Gowlett JAJ, Parfitt SA, Bridgland DR, Lewis SG. 2006. Humans in the Hoxnian: Habitat, context and fire use at Beeches Pit, West Stow, Suffolk, UK. J Quat Sci 21: 485-496.

Purslow PP. 2005. Intramuscular connective tissue and its role in meat quality. Meat Sci 70: 435-477.

Qi BX, Moore KG, Orchard J. 2000. Effect of cooking on banana and plantain texture. J Agric Food Chem 48: 4221-4226.

Ragir S. 2000. Diet and food preparation: Rethinking early hominid behavior. Evol Anthropol 9: 153-155.

Rerat A, Calmes R, Vaissade P, Finot PA. 2002. Nutritional and metabolic consequences of the early Maillard reaction of heat treated milk in the pig: Significance for man. Eur J Nutr 41: $1-11$.

Roe CF, Kinney JM. 1965. The caloric equivalent of fever. II. Influence of major trauma. Ann Surg 161: 140-147.

Rosell M, Appleby P, Key T. 2005. Height, age at menarche, body weight and body mass index in life-long vegetarians. Public Health Nutr 8: 870-875.

Secor SM. 2003. Gastric function and its contribution to the 
postprandial metabolic response of the Burmese python, Python molurus. J Exp Biol 206: 1621-1630.

Secor SM, Boehm M. 2006. Specific dynamic action of ambystomatid salamanders and the effects of meal size, meal type, and body temperature. Physiol Biochem Zool 79: 720-735.

Secor SM, Diamond J. 1995. Adaptive responses to feeding in Burmese pythons: Pay before pumping. J Exp Biol 198: 13131325.

Secor SM, Faulkner AC. 2002. Effects of meal size, meal type, body temperature, and body size on the specific dynamic action of the marine toad, Bufo marinus. Physiol Biochem Zool 75: 557-571.

Seiquer I, Diaz-Alguacil J, Delgado-Andrade C, Lopez-Frias M, Hoyos AM, Galdo G, Navarro MP. 2006. Diets rich in Maillard reaction products affect protein digestibility in adolescent males aged 11-14 y. Am J Clin Nutr 83: 1082-1088.

Sergant J, Crombé P, Perdaen Y. 2006. The 'invisible' hearths: A contribution to the discernment of Mesolithic non-structured surface hearths. J Archaeol Sci 33: 999-1007.

Shipman P, Walker A. 1989. The costs of becoming a predator. $J$ Hum Evol 18: 373-392.

Shorrock C, Ford JE. 1978. Metabolism of heat-damaged proteins in the rat: Inhibition of amino acid uptake by 'unavailable peptides' isolated from enzymic digests of heat-damaged cod fillet. Br J Nutr 40: 185-191.

Sillen A, Hall G, Armstrong R. 1995. Strontium calcium ratios $(\mathrm{Sr} / \mathrm{Ca})$ and strontium isotopic ratios $\left({ }^{87} \mathrm{Sr} /{ }^{86} \mathrm{Sr}\right)$ of Australopithecus robustus and Homo species. J Hum Evol 28: 277-285.

Silvester KR, Englyst HN, Cummings JH. 1995. Ileal recovery of starch from whole diets containing resistant starch measured in vitro and fermentation of ileal effluent. Am J Clin Nutr 62: 403-411.

Somel M, Creely H, Franz H, Mueller U, Lachmann M, Khaitovich P, Pääbo S. 2008. Human and chimpanzee gene expression dif- ferences replicated in mice fed different diets. PLOS ONE 3: e1504.

Tester RF, Sommerville MD. 2000. Swelling and enzymatic hydrolysis of starch in low water systems. J Cereal Sci 33: 193-203.

Tester RF, Qi X, Karkalas J. 2006. Hydrolysis of native starches with amylases. Anim Feed Sci Technol 130: 39-54.

Thieme H. 2005. The Lower Paleolithic art of hunting. In The hominid individual in context: Archaeological investigations of Lower and Middle Paleolithic landscapes, locales and artefacts (ed. CS Gamble and M Parr), pp. 115-132. Routledge, London.

Tishkoff SA, Reed FA, Ranciaro A, Voight BF, Babbitt CC, Silverman JS, Powell K, Mortensen HM, Hirbo JB, Osman $\mathrm{M}$, et al. 2007. Convergent adaptation of human lactase persistence in Africa and Europe. Nat Genet 39: 31-40.

Toth N, Schick K, Eds. 2006. The Oldowan: Case studies into the earliest Stone Age. Stone Age Institute Press, Gosport, IN.

Waldron KW, Parker ML, Smith AC. 2003. Plant cells walls and food quality. Compr Rev Food Sci Food Safe 2: 101-119.

Westerterp KR. 2004. Diet induced thermogenesis. Nutr Metab 1: $1-5$.

Westerterp KR, Wilson SAJ, Rolland V. 1999. Diet induced thermogenesis measured over $24 \mathrm{~h}$ in a respiration chamber: Effect of diet composition. Int J Obesity 23: 287-292.

Wobber V, Hare B, Wrangham R. 2008. Great apes prefer cooked food. J Hum Evol 55: 340-348.

Wrangham R. 2009. Catching fire: How cooking made us human. Basic, New York.

Wrangham RW, Conklin-Brittain NL. 2003. Cooking as a biological trait. Comp Biochem Physiol A 136: 35-46.

Wrangham RW, Jones JH, Laden G, Pilbeam D, Conklin-Brittain NL. 1999. The raw and the stolen: Cooking and the ecology of human origins. Curr Anthropol 40: 567-594. 


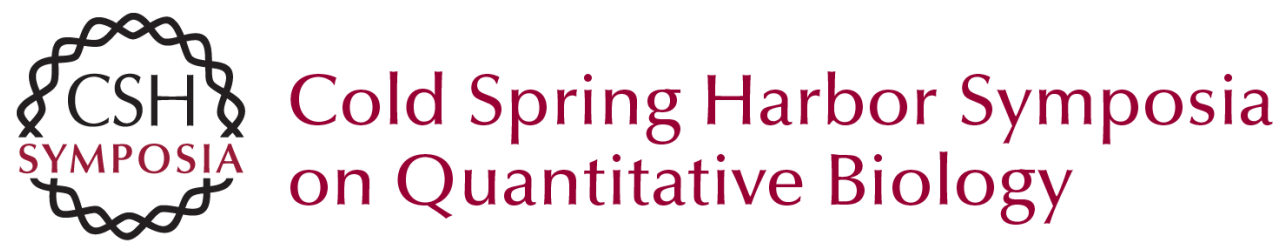

\section{Cooking and the Human Commitment to a High-quality Diet}

R.N. Carmody and R.W. Wrangham

Cold Spring Harb Symp Quant Biol 2009 74: 427-434 originally published online October 20, 2009 Access the most recent version at doi:10.1101/sqb.2009.74.019

References This article cites 71 articles, 9 of which can be accessed free at: http://symposium.cshlp.org/content/74/427.full.html\#ref-list-1

License

Email Alerting Receive free email alerts when new articles cite this article - sign up in the box at the Service top right corner of the article or click here.

To subscribe to Cold Spring Harbor Symposia on Quantitative Biology go to:

http://symposium.cshlp.org/subscriptions 